AMERICAN JOURNAL OF SOCIAL AND MANAGEMENT SCIENCES

ISSN Print: 2156-1540, ISSN Online: 2151-1559, doi:10.5251/ajsms.2011.2.1.21.25

(C) 2010, ScienceHuß, http://www.scihub.org/AJSMS

\title{
Emotional intelligence and parental involvement as predictors of academic achievement in financial accounting
}

\author{
Adetayo, Janet Oyebola and Kiadese, Adeola Lukman \\ Department of Curriculum Studies and Instructional Technology, Olabisi Onabanjo University, \\ Ago-Iwoye.
}

\begin{abstract}
This study investigated Emotional Intelligence and Parental Involvement as Predictors of Students' Achievement in senior secondary financial accounting in Ifo Local Government of Ogun state, Nigeria using survey research design of correlational type. A total of two hundred SS II financial accounting students selected through simple random sampling technique participated in the study. Three research questions were raised and answered at 0.05 level of significance. Two validated instruments: emotional intelligence and parental involvement rating scale (EIPRS) and Financial Accounting Achievement Test (FAAT) were the major instruments used for data collection. The Pearson moment correlation and multiple regression analysis were the statistical tools used for data analysis. Findings from the study revealed that both emotional intelligence and parental involvement predict students' achievement in Financial Accounting. It was recommended among others that counselors and teachers should work on the emotional well being of the students in the school, while the parent should be positively disposed to the academic pursuit of their children.
\end{abstract}

Keywords: Academic achievement, financial accounting, emotional intelligence

\section{INTRODUCTION}

Financial accounting is one of the vocational subjects offered at the senior secondary level of education in Nigeria. The vocational subjects such as technical drawing, typewriting, and shorthand form part of the curriculum of the senior secondary education. The financial accounting is tremendously important to the economy of Nigeria, as it provides a solid foundation for the training of future accountants, managers and entrepreneurs (Aluwong, 2002). Every individual irrespective of its class require the knowledge of accounting to meet its day to day activities. Noran (2006) buttresses this point, when he says accounting is the language of business and everyday activities.

The general objectives of financial accounting as stated in the National Curriculum include for senior secondary schools (1985) are to provide:

i. Specialized instruction to prepare students for careers in the book-keeping and accounting field;

ii. Fundamental instruction to help students assume their economic role as consumers, workers and citizen;

iii. Background instruction to assist students in preparing for other professional careers requiring advanced study in book keeping and accounting;

iv. Book keeping and Accounting skills for personal use in the future with particular emphasis on wise planning of income and expenditure.

However, documentary evidence revealed students poor performance in Financial Accounting despite its laudable and well articulated objectives. The WAEC chief examiners report (2008) also showed students abysmal performance in the subject. The trends in students' performance in the subject have been a source of concern to Business Educators about the future career of students offering the subjects.

Academic performance (most especially of secondary school students) has been largely associated with many factors. In recent time, literature has shown that learning outcomes (academic achievement and academic performance) have been determined by such variables as: family size, society and motivational factors (Aremu \& Sokan, 2003; Aremu \& Oluwole, 2001). In the same vein, Parker, Creque, Harris, Majeski, Wool, and Hogan (2003) noted that much of the previous studies have focused on the impact of demographic and socio-psychological variables on academic achievement. More recently, another emerging dimension to the determinant of 
academic achievement is the students personal and teachers' factor (Adekola, 2008).

In spite of the seeming exhaustiveness of literature on the determinants of academic achievement of learners, there seems to be more area of interest and variables to be investigated such as emotional intelligence and parental supportiveness among others. Emotional intelligence is a relatively recent behavioural model.

Mayer and Salovey (1987) postulated that emotional intelligence involves the ability to perceive accurately, appraise and express emotion, ability to access and to generate emotional knowledge, and the ability to promote emotional and intellectual growth. Again Salovey and Mayer (1993) wrote that an emotionally intelligent person is skilled in four area: identifying, using, understanding, and regulating emotions. Similarly, Goleman (1995) also stressed that emotional intelligence consists of five components: knowing ones emotions (self awareness), managing them, motivating self, recognizing emotions in others (empathy) and handling relationships.

Researches are beginning to uncover the relationship between emotional intelligence with other phenomena. These are leadership (Ashfort \& Humphrey, 1995); group performance (Williams \& Sternberg, 1988) and academic achievement (Aremu, 2006). The foregoing attest to the significance of emotional intelligence to all constructs (school achievement inclusive). Finnegan (1988) argued that school should help students to learn the abilities underlying the emotional intelligence. This he believes could lead to achievement from formal education years of the child.

Parker, Summerfeld, Hogan and Majeski (2002) reported that various emotional and social competencies were strong predictors of academic success. Similarly, Aremu (2006) found emotional intelligence to be significant predictor of academic success. In the same vein Low and Nelson (2004) reported that emotional intelligence skills are key factors in the academic achievement and test performance of high school and college students respectively.

Likewise, Abisamra (2004) reported that there is a positive relationship between emotional intelligence and academic achievement. He therefore canvassed for inclusion of emotional intelligence in the school curricula.
Parents among others also constitute a powerful factor that can influence the overall academic performance through regular visitation and involvement in students' academic work (Ojedele, 2006). Epstein (1997) identified five main components of parental involvement as:

i. parents fulfilling their obligation towards their children i.e. providing food, clothing, shelter etc.;

ii. parents providing academic instruction;

iii. parents participating in activities in school;

iv. parents mediating home-based learning activities;

v. parents providing support and reinforcement of school based learning and conduct.

Further studies on parental involvement and academic achievement; have shown to date that the two constructs seem to be positively related. Findings have demonstrated that parents' involvement in the education of the children has been found to be of benefit to parents, children and school (Tella and Tella, 2003; Campbell, 1995; Rich, 1987). Ransinki and Fredrick (1988) reported that parents play an invaluable role in laying the foundation for their children learning; Zang and Carrasquillo (1995) also similarly remarked that when children are surrounded by caring, capable parents and are able to enjoy nurturing and moderate competitive kingship, a foundation for literacy is built with no difficulty.

Cotton and Wikelund (2005) ably capped it by asserting that the more intensively parents are involved in their children learning: the more beneficial are the achievement effects. Thus, it is believed that when parents monitor homework, encourage participation in extra curricular activities, are active in parents-teacher associations, and help children develop plans for their future; children are more likely to respond and do well in school. Campbell (1995) observed that high levels of parents involvement in their children education result in higher students achievement; higher attendance levels; a decline in dropout rates; fewer disciplinary problems; and better students motivation, self esteem and behaviour. Nevertheless, there is still a need to further investigate the relationship among emotional intelligence, parental involvement and students' achievement in Financial Accounting at secondary level of education especially in country like Nigeria. 
Research questions: The following research questions were raised to guide the conduct of this study:

i. Is there any significant relationship between the independent variable (emotional intelligence and parental involvement) and dependent variable (students' achievement in financial accounting).

ii. Will the predictor variables (emotional intelligence and parental involvement) jointly predict students' achievement in financial accounting?

iii. What is the relative contribution of emotional intelligence and parental involvement to students' achievement in financial accounting?

\section{METHODS}

The correlational survey research design was adopted in this study. A total of 200 senior secondary school II Financial Accounting students selected through simple random sampling techniques from five secondary schools in Ifo local government of Ogun state, participated in this study. Two research instruments were used for data collection. The students' emotional intelligence and parental involvement rating scale (SEIPIRS) and Financial Accounting Achievement Test (FAAT). The SEIPIRS has three sections. Section A contained a personal data in which participant were expected to elicit information on their gender, age and class. Section $B$ of the SEIPIRS contains 33 items on emotional intelligence adapted from the emotional intelligence scale developed by Schutter, Haggerty, Cooper, Golden \& Dornhein, 1998, with a Cronbach alpha of 0.90 for internal consistency and 0.78 test-retest reliability. The response format for the instrument is a 4-point likert scale of: 1 = Strongly Disagree, 2 = Disagree, $3=$ Agree and $4=$ Strongly Disagree. Two examples of item in this section are:

- I know when to speak about my personal problems to others.

- When I am faced with obstacles, I remember times faced similar obstacles and overcame them.

The section $C$ of SEIPIRS is on parental involvement. This contained a 20 items statement structured on a 4 point rating format $(4=$ Strongly Agree, $3=$ Agree, 2 = Disagree, 1 = Strongly disagree. Items in this section were as well adapted from Fantuzzo, Tighe \&
Child (2000) family involvement questionnaire. Two examples in this section are:

My parents always check my school work.

My parents always reward me each time I perform very well.

Using a split-half method and Co-efficient Alpha method a reliability of 0.59 and 0.71 respectively were returned for section $\mathrm{C}$ of the instrument.

The second instrument which is the Financial Accounting Achievement Test (FAAT) comprised of 50 multiple choice questions with 5 options per item drawn from NECO curriculum in senior secondary school Financial Accounting. The face and content validity of FAAT was established by two experienced Financial Accounting teachers and three NECO examiners. It also yielded a reliability coefficient of 0.65 using test retest technique. The item analysis of the instrument was also conducted in other to determine the difficulty and discrimination indices of the items.

Regards procedure permission were obtained from the principals of the sampled schools after which the researchers with the assistance of the subject teachers administered the two instruments on the participants. The instruments were collected back from the students after the administration for scoring and analysis. The data collection exercise lasted for two weeks.

\section{RESULTS AND DISCUSSION}

Question 1: Is there any significant relationship among the variables of interest?

Table 1: Results of Correlation Analysis among variables of interest

\begin{tabular}{|c|c|c|c|c|c|}
\hline Variables & $\mathrm{N}$ & Mean & S.D & $\begin{array}{c}\text { Pearson } \\
r\end{array}$ & $\begin{array}{l}\text { Sig. } \\
\text { of } P\end{array}$ \\
\hline $\begin{array}{l}\text { Achievement } \\
\text { scores }\end{array}$ & 200 & 74.35 & 5.756 & 1.00 & \\
\hline $\begin{array}{l}\text { Emotional } \\
\text { Intelligence } \\
\text { scores }\end{array}$ & 200 & 71.58 & 6.796 & 0.69 & 0.000 \\
\hline $\begin{array}{l}\text { Parental } \\
\text { Involvement } \\
\text { scores }\end{array}$ & 200 & 69.12 & 4.553 & 0.74 & 0.000 \\
\hline
\end{tabular}

The result in table 1 revealed a significant outcome. The result showed that the relationship between the students' achievement and emotional intelligence 
Am. J. Soc. Mgmt. Sci., 2011, 2(1): 21-25

scores $(r=0.69)$ is very high, positive and significant. The relationship between the students' achievement and parental involvement scores $(r=0.74)$ is also high, positive and significant. Hence, there exist a positive and significant relationship between the possible pairs of independent and dependent variables.

Question 2: Will the predictor variables, when combined, significantly predict students' academic achievement in Financial Accounting?

Table 2: Summary of the regression Analysis

$$
\begin{array}{ll}
\text { Multiple R } & =0.760 \\
\text { R2 } & =0.577 \\
\text { Adjusted R2 } & =0.573 \\
\text { Standard Error } & =3.7607
\end{array}
$$

Analysis of Variance table

\begin{tabular}{|l|l|l|l|l|l|}
\hline Source & Df & $\begin{array}{l}\text { Sun of } \\
\text { Squares }\end{array}$ & $\begin{array}{l}\text { Mean } \\
\text { Squares }\end{array}$ & F & Sig. \\
\hline Regression & 2 & 3807.636 & 1903.82 & 134.61 & .000 \\
Residual & 197 & 2786.159 & 14.14 & & \\
\hline Total & 199 & 6593.795 & & & $\mathrm{P}<0.05$ \\
\hline
\end{tabular}

The result in Table 2 revealed a significant outcome $(F[2,197]=134.61, P<0.05$. This implied that the predictor variables jointly and significantly predict the dependent variable (achievement of students in Financial Accounting). The ANOVA Table further revealed that the predictor variables, when combined together accounted for more than $57 \%$ of the total variance observed in performance $(R=0.760, F=$ 134.61 and $P<0.05)$.

Question 3: What is the relative contribution of emotional intelligence and parental involvement to students' achievement in financial accounting?

Table 3: Relative Contributions of the Predictor Variables on Academic Achievement

\begin{tabular}{|l|c|c|c|c|c|}
\hline \multirow{2}{*}{ Model } & \multicolumn{2}{|l|}{ Unstandardized Coefficients } & $\begin{array}{l}\text { Standardized } \\
\text { Coefficients }\end{array}$ & & \\
\cline { 2 - 6 } & B & Std. Error & Beta & t & Sig. \\
\hline (Constant) & 11.824 & 4.134 & & 2.860 & 0.005 \\
Emotional Intelligence & 0.216 & 0.067 & 0.255 & 3.228 & 0.001 \\
Parental Involvement & 0.681 & 0.100 & 0.539 & 6.830 & 0.000 \\
\hline
\end{tabular}

The result in table 3 revealed the relative contribution of each of the predictor variables to the variance in the dependent measure. In term of predicting students' performance in Financial Accounting, parental involvement contributed the highest, explains about $54 \%(B=0.681, t=6.830, P<0.05)$ and emotional intelligence contributed about 25\% (B $=0.216, t=3.228, P<0.05)$ of the total variance in the students performance in Financial Accounting.

\section{DISCUSSION AND CONCLUSION}

In this study three research questions were raised and answered. Findings from research question 1 revealed a positive and significant relationship between emotional intelligence, parental involvement and students' achievement in Financial Accounting. This finding is consistent with previous findings of (Parker, 2003; Aremu, Adeyinka \& Tella, 2007) on the relationship between emotional intelligence, parental involvement, and academic success among secondary school students. Similarly, Abisambra (2000) had reported that there is a positive relationship between emotional intelligence and academic achievement among adolescent students.

In this study, it was also found that parental involvement and emotional intelligence predicted academic achievement in Financial Accounting of Secondary school II students in Ifo Local Government in Ogun State. This finding is supported by the study of (Tella \& Tella, 2003; Simeon, 2003). Thus, it is not out of research context to assert that the degree of the parent involvement in the education of their wards would determine the degree of their children academic achievement. This assertion is consistent with the view of Schickedanz (1995) in which he reported that children whose parents are passive perform poorly academically. This outcome also supported the findings of Aremu et al (2007) that emotional intelligence is a good predictor of 
academic success and achievement. The results of the third research question further confirm the first and second findings of the study by revealing that both emotional intelligence and parental involvement had a significant relative contribution to the academic achievement of students in Financial Accounting in Ifo local government of Ogun State. It is reasonable therefore to note that both emotional intelligence and parental involvement are good factors of academic achievement in Financial Accounting of Senior Secondary School Students in Ifo local government of Ogun State. These findings have some implication. First, parent should note that their interpersonal relationship and direct interest in the academics of their children could bring a better academic performance. Thus, effort should be made by them to be positively disposed to academics of their children. Two, both home and school need to cooperate in making the learners to be well adjusted emotionally as this could make or mar their academic achievement. It is therefore recommended that teacher and counselling psychologist in the school should work on the emotional well-being of students in the school.

\section{REFERENCES}

Abisamra, N. (2000). The relationship between emotional intelligence and academic achievement in Eleventh Graders. Research in education, 4: 56-66.

Adekola, B.O. (2008). Some Predictors of Students Achievement in English Grammar and Comprehension in Ogun State Public Senior Secondary Schools. A Ph.D. post-field report presented at the Departmental Seminar of Curriculum Studies and Instructional Technology, Olabisi Onabanjo University, Ago-Iwoye.

Aluwong, S.W. (2002). The Impact of goal structures on students' performance in Accounting. Unpublished Ph.D. Thesis, Ahmadu Bello University, Zaria, Nigeria.

Ashfort, B.E. \& Humphrey, R.H. (1995). Emotion in work place: An appraisal . Human relation, 48(2), 613-619.

Camphell, J. (1995). Raising your child to be gifted. Cambridge; Brookline books. Cotton, K. \& Wikelund, K.R. (2005). Parent Involvement in education. Available at: http:/www.nwrel.org. Accessed, 28/11/08.
Epstein, J.L. (1997). School, family and community partnership: Your handbook for action. Thousand Oaks, Ca: Crown in Press.

Fantuzzo, J.; Tighe, E.; \& Childs, S. (2000). Family involvement questionnaire: A multivariate assessment of family participant in early childhood education. Journal of education psychology, 92 (2), 377-390.

Finnegan, J.E. (1998). Measuring emotional intelligence: Where we are today. Document Reproduction Service No. ED 426087.

Goleman, D. (1995). Emotional Intelligence: Why it can matter more than IQ. New York; Bantam Books.

Low, G.R. \& Nelson, D.A. (2004). Emotional Intelligence; Effectively bridging the gap between high school and college. Texas study magazine for secondary education, spring edition.

Parler. J.D.A.; Cresques, R.; Haris, J.; Majeski, S.A.; Wood, L.M. \& Hogan M.J. (2003). Academic Success in High School: Does Emotion Matter? ERIC

Schickedanz, J.A. (1995). Family socialization and academic achievement. Journal of education, 1, 1734.

Schutter, N.A.S.; Malouf, J.M.; Haggerty, D.; Cooper, J.T.; Golden, C.J.; \& Dorheim, L. (1998). Development and validation of a measure of emotional intelligence personality and individual differences, 25, 167-177.

Salovey, P.; \& Mayer, J.D. (1993). The intelligence of emotion. Intelligence, 17, 433-442.

Tella, A. \& Tella, A. (2003). Parental Involvement, home background and school environment as determinant of academic achievement of secondary school students in Osun State, Nigeria. Africa Journal of Cross Cultural Psychology and Sport Facilitation, 5 (2), 4248.

West Africa Examination Council (2008). Highlights of statistics of entries, 2000-2008. Yaba, Lagos; Test Development and Research Division.

Zang, S.Y. \& Carrasquillo, A.L. (1995). Chinese parents influence on academic performance. New York State Association for Bilingual education Journal, 10, 46-53. 